\title{
'I think my son is a wonderful chap' \\ Working-class and middle-class fathers' narratives of their son's ADHD diagnosis and medication
}

\section{Introduction}

In the rich literature on 'new fathers' there is an emergent focus on the role of class in shaping fathering practices and identities. According to time-use measures, the new 'hands-on-father' involved in the daily activities of childcare (Brannen and Nielsen, 2006) is most evident among middle-class fathers (Sullivan, 2010). Indeed, this new father is subject to much critical scrutiny (Bekkengen, 2006; Johansson and Klinth, 2008). Yet, so far, the persistent emphasis on this specific configuration of emotionally involved fathering may have the unintended consequence of assigning working-class fathers the role of those lagging behind in a movement towards one particular form of emotional involvement (Plantin 2007; Farstad and Stefansen, 2015). An emergent focus on how various material and cultural life situations shape different configurations of fatherhood and emotional involvement offers a promising way out of this impasse (Brannen and Nielsen, 2006; Plantin 2007; Braun et al., 2010; Stefansen and Farstad, 2015). In this article, we will provide an enhanced insight into the complex issue of emotional involvement by examining how middle-class and working-class fathers relate to their sons' ADHD diagnosis. Diagnosis and medical treatment of ADHD often entail difficult dilemmas for parents concerning their child's well-being and educational success. We will use this as a lens through which we explore how the entwinement of gendered and classed perceptions informs men's fathering practices and emotional involvement with their children. Drawing on a narrative interview study of fathers of boys diagnosed with ADHD (Olsvold, 2012), we describe classed differences in fathers' narratives around their sons' ADHD diagnosis and medication. These different narratives contribute to enhanced insight into how classed experiences and life situations play into and shape different formations of masculinity and emotionally involved fathering.

\section{Classed masculinities, intensive parenting and ADHD}

A major preoccupation in much literature on fathering is to carve out the dynamics that drive more emotionally involved and egalitarian parenting, leaving behind the emotionally distant and authoritarian traits of hegemonic masculinity (Finn and Henwood, 2009; Coltart and 
Henwood, 2012; Dolan, 2014). Yet, more recent engagement with the classed underpinnings of fathering draws attention to how fathers' emotional involvement must be understood in relation to their classed life situations (Plantin, 2007; Aarseth, 2009; Braun et al., 2011; Stefansen and Farstad, 2015). According to this literature, the particular formation of 'handson-fathering' highlighting involvement in everyday practicalities could be seen as part of a 'dyadic turn' (Dermott, 2008) in families that attracts middle-class parents more than other groups (Aarseth, 2009; Stefansen and Aarseth 2011; Farstad and Stefansen, 2015). More particularly, this dyadic turn could be seen as evidence of more individualized family cultures where emotional bonds are conceived of as something that need to be achieved and worked at. Thus, several studies of classed fathering practices describe a pattern in which interviewees belonging to the professional middle class expressed an urgent need to develop an emotional bond with their child and perceived this as something that required special attention and efforts (Plantin, 2007; Aarseth, 2009; Stefansen and Aarseth, 2011; Farstad and Stefansen, 2015). Importantly, these bonds are person-centred; that is, the relationships are seen as intrinsically dependent on the unique qualities of the person (Bernstein 1977; Stefansen and Aarseth, 2011). By contrast, men from working class backgrounds tend more often to conceive of emotional bonds as something that emerge 'naturally' as part of being a family (Plantin, 2007; Farstad and Stefansen, 2015). Here, the relationships are less dependent on the entwinement of unique personal qualities, but rather founded on the workings of the family unit (Farstad and Stefansen, 2015). Also, as Plantin points to (2007), fathering does not depend on a radical transformation, a unique possibility to become 'a new person' but appears to be conceived of largely in terms of continuity and an experience that may unearth deepseated gendered experiences from one's own childhood (see also Brandt, 2012; Coltart and Henwood, 2012).

Not surprisingly, these differences in fathering practices are consistent with patterns described in the literature on classed parenting practices more generally (Braun et al., 2011). Notably, the above patterns resonate with the classed parenting styles first captured by Annette Lareau (2003) which vary between orientations towards parenting as assisting children's 'natural growth' versus engagements with a 'concerted cultivation'. While the first is more evident among working-class families, middle-class parents seem more oriented towards a 'concerted cultivation', an intensive and continuous investment in their children's personal capabilities and future prospects.

Arguably, such patterns of classed differences in parenting styles and the different formations of emotional involvement become particularly pressing in the current situation in 
which more intensive demands are directed towards parents (Vincent and Ball, 2007). In fact, it may be worthwhile to bear in mind that these increased expectations of 'hands-on fathering' coincide with these new requirements (Gottzén and Kremer-Sadlik, 2012). Parents are increasingly expected to invest in their children's future, that is, to engage with what Lareau described as 'concerted cultivation' parenting. Particularly in the USA and UK, researchers depict a wide-reaching responsibilization of parents (Vincent and Maxwell, 2016) that generates a deep-seated anxiety for the future prospects of their offspring. In these countries, researchers describe an anxiety-driven investment in children that even includes a willingness to trade the children's well-being for their future prospects (Walkerdine et al., 2001; Reay 2000). These new requirements seem particularly hard to resist and the urge to secure their children's life chances seem to prevail even among parents that profess other values (Reay et al., 2011).

The current more widespread practice of ADHD diagnosis and medical treatment serves to illustrate the intensive demands on parenting. ADHD medication may be a way to seek relief from the significant threat of an underperforming child, sometimes both in social relationships and with regard to school achievement and the subsequent educational trajectory. In the USA, ADHD diagnosis increased from 7.8\% in 2003 to $11 \%$ in 2011, and boys (13.2\%) are more likely to be diagnosed with ADHD than girls (5.6\%) (CDC, 2015). Although no clear evidence for a discrete neurobiological disease or condition has yet been found (Furman, 2009), the medical discourse on ADHD has become the dominant official discourse in most Western societies (Conrad, 2010, 2006; Frigerio et al., 2013; Timimi, 2009). Alternative paradigms for ADHD are explored from an anti-medicalization perspective, including the notion that today's children and parents are distressed, not medically ill (Conrad, 2010, p. $529)$.

However, although the level of anxiety and future-orientation seem less prevalent in the Nordic countries than in their Anglo-Saxon counterparts (Doepke and Zilibotti, 2014), ADHD diagnosis is remarkably widespread in the Nordic countries. After Iceland, Norway diagnoses and medicates proportionally the most children for ADHD (Zoëga et al., 2011). More than 17 500 children and young people are on medication for ADHD (Lunde, 2011), and prescription refunds of ADHD medication have increased from 19 million Norwegian kroner in 2002 to nearly 200 million in 2011 (Idås, 2011). One possible reason for this is the emphasis placed on 'fitting in' and 'going along' (Smette, 2015), both in social relationships and in the school context. Another important factor, though, is probably the fact that diagnosis is considered to 
be a precondition for gaining the necessary extra resources in the educational setting (Olsvold, 2012).

In this context, parents must make decisions about whether to act according to the expected official medical discourse by referring their child for assessment in a psychiatric clinic if the child's behaviour can be interpreted as possibly symptomatic of ADHD and, if diagnosed, how to treat their child's condition - with or without the help of drugs. In these negotiations and decisions, a noticeable gender difference seems to emerge. Anglo-American studies find that fathers tend to be more critical of the diagnosis and drug treatment than mothers (Singh, 2003; Chen et al., 2008). While mothers appear to see ADHD as a biologically based disorder, fathers are more likely to explain ADHD behaviour by referring to indulgent mothering, boys' lack of motivation and a 'boys will be boys' rationale (Singh, 2003, p. 311). Chen et al. (2008, p. 97) suggest that fathers are more reluctant to accept the medical discourse because they rarely attend meetings with health professionals, and therefore are less exposed to the professional view of the nature of ADHD than mothers. Fathers' resistance to ADHD diagnosis is thus accounted for in terms of a more general notion of fathers' lack of involvement and lesser emotional and moral responsibility for their children (see Doucet 2007; Dermott, 2009; Shirani et al., 2011). By carefully examining fathers' situated experiences of their sons' ADHD diagnosis, this article will complicate this notion of a general lack of involvement, turning the gaze instead towards different forms of emotional involvement. More particularly, we suggest that the way in which fathers relate to ADHD diagnosis provides a fruitful source of deeper insight into the role of classed experiences in the shaping of different configurations of fathers' emotional investment.

\section{Sample and methods}

The analysis draws on in-depth interviews with 16 fathers of boys diagnosed with ADHD. The interviews were conducted as part of a larger study that also included interviews with 19 mothers, 17 boys and two girls (Olsvold, 2012). The fact that the majority in the sample are boys is partly because boys are more often diagnosed with ADHD, and therefore more boys were recruited to the project. The predominance of boys in the sample allowed a more explicit emphasis on the particular challenges that are typical for boys, namely a higher level of hyperactivity and impulsivity, as well as a closer examination of the variations in managing this form of 'difficult masculinity'. At the time of the interviews all the children, between the ages of eight and fourteen, were receiving drug treatment for ADHD. The interviewees were 
recruited through four outpatient clinics for child and adolescent psychiatry. ${ }^{i}$ Each child was interviewed twice and the mothers and fathers once. All except four interviews took place in their homes.

The study involves one group of middle-class and one group of working-class fathers, categorized by level of education and type of occupation. Seven of the fathers had higher education (bachelor's or master's degrees) and professional careers. One of the fathers with only upper secondary education had a managerial position in business and a high income, and is for this reason categorized as middle class despite his lack of a university degree. Seven fathers had little or no education after lower secondary school and had skilled or unskilled manual work. However, one of the fathers had recently started his own business. All the working-class fathers were the main providers in the family and they practised a traditional division between female caregiving and male breadwinning. In contrast, many of the middleclass fathers had wives who worked full-time, and according to their narratives they shared daily responsibility for their children with their partners. The manner of involvement varied somewhat. Some of the middle-class fathers seemed primarily to assist their partner with upbringing, while other middle-class couples seemed to practise more equally shared childcare.

The interviews were based on the free association narrative interview method (Hollway and Jefferson, 2005; Olsvold, 2012). Using this method, the interviewer does not ask directly about a specific topic but asks questions that aim to elicit free association narratives about everyday life with a child diagnosed with ADHD. More particularly, the participants were encouraged to tell the interviewer everything they did together with their child during an ordinary day, such as waking up, getting themselves and their child ready for school, medication routines, returning home, evening at home and organizing bedtime for their child. Notably, the structure and organization of everyday life did not constitute our research interest as such. Instead, the chronology of activities during one particular day was used as an organizing device for the interview (Andenæs, 2005). We were especially interested in the narrative themes - that is, the episodes chosen by the father, the stories told about these specific experiences and the associations and emotions evoked. The data consisted of audio files, transcribed audio files, process notes and observations (not systematized) from the four visits to the home of each family. The analysis was organized around different stages: first, an unfocused reading and rereading of the text including a recording of notes as a way of documenting the researchers' associations to the text. Following this, themes and discourses were identified and the data structured into categories for analysis that could be compared 
across the fathers' interviews, also with links and threads to the interviews with the mothers and children.

Furthermore, the analysis was inspired by psychosocial narrative research methods (Hollway and Jefferson, 2005). Here, the emphasis on discursive positions and meaningframes is combined with an emphasis on the individual psyche and the experiencing self (Coltrart and Henwood, 2013). More specifically, the analysis centres on the narrative interpretations of the interviewees, and how they draw on or invest in various discourses in order to make sense of the world. Thus, our main focus is on how these fathers perceive and form stories about their sons' ADHD and how they draw on and invest in different cultural discourses of boyhood and masculinity.

\section{Two narratives - similarities and differences}

Generally, the fathers were more resistant to a medical understanding of their sons' behaviour and tended to characterize drug treatment more negatively than the mothers (Olsvold, 2012). Also, it seems that the fathers have generally had a more distant role in the process related to the ADHD assessment than the mothers. In only one of the interviewed families was it the father who initially wanted an ADHD assessment. In the remaining cases it was either the mother or the school who took this initiative. Both groups of fathers displayed more critical views of the way the school had been handling their sons and they also identified more with their sons' behaviour. However, there are noticeable differences in the narratives of the working-class and middle-class fathers with regard to the way they expressed their resistance and criticism. It is these differences that are our focus in this article. We suggest that these differing patterns allow us to gain enhanced understanding of how classed masculinities play out in these fathers' involvement with their sons.

\section{'Boys will be boys' - working class fathers' narratives}

In the narratives of the working class fathers the diagnosis and drug treatment tended to be regarded as the mother's project. Most of these fathers were unwilling to fully comply with the diagnosis and medicalization discourse. While acknowledging that their son had a somewhat high level of activity, they generally did not consider him as deviant. On the contrary, they emphasized that their son's behaviour did not differ from their expectations: 'I expect a fairly high level of activity in boys, really'. Frank, another father, thought he had a 
different threshold of tolerance for activity in his son than the mother had, which 'does not allow him to be a boy'.

As mentioned above, these families generally seemed to adhere to more gendersegregated norms and practices in their everyday lives, where mothers were largely viewed as responsible for decisions relating to the children. The general impression was that the diagnostic assessment and the drug treatment were something the fathers went along with to support the mothers or to avoid conflict. Jack said that he had not prevented the mother from taking their son for a diagnostic assessment, but he made it clear that this was not something he believed in:

I thought that she overreacted a little at times. But, yeah. Not that I have said 'no, you're not allowed to go to the clinic with him', or 'no, you have to stop this because it's just nonsense.'

Others were more supportive. They felt that the mother was a better judge than themselves concerning the children. They left it for the mothers to decide what was in their child's best interest. According to Paul, a main reason for the drug treatment was the conflicts that arose between his wife and their son over homework. Because he had to work late every evening so the family could afford to go on holiday, he was unable to provide support in these difficult situations. Despite their doubts, some of the fathers expressed compassion for their wives: 'But it is she who has to take the burden - what is going on and why is he so active?' These fathers knew that it was a heavy burden on their wives to be the person responsible for bringing the son in for the ADHD assessment and for follow-up appointments with health professionals and the school.

Another pattern that emerged in the interviews with the working-class fathers that support this notion of ADHD diagnosis as 'a women's issue' is a particular narrative of authority. Several of these fathers pointed out that their sons showed more respect for them than for the mother: 'He is not difficult with me. Of course I am a man, to put it that way; he does have more respect for me than for his mother.' Unlike the mothers, these fathers assert that they are able to set clear boundaries between themselves and their sons: 'I have full control in my relationship with him.' They rather assertively claim that due to the respect they have for their father, their sons have no need for a drug. It is the mother and the teacher who perceive that need. Oliver, who is divorced from his wife and has his son to visit every second weekend, said: 
Well, I have no problem when my son is here. If he starts to quarrel and fight, I just give him a sign. He does have respect, you know. I just have to say, enough is enough. [....]. Because he knows that if I get annoyed, then that is the end of computer games and stuff like that here. [...]. But I know he can argue more with his mother. That is just how it is. Because I also remember when the hubby came home, then it was quiet in the playground, that's for sure. No one could stop me when I was little, except my father.

Oliver explains that he raises his son in the same way as he was brought up himself. He used to obey his father, and he expects his son to do the same. This is a type of obedience that demands that the son submits to authority - his father. This type of father does not need a tablet to make his son behave. Importantly, not all the working-class fathers portrayed themselves as equally tough and hard in relation to their sons. Jonathan says that his son is quiet around him even though he is not picking on him all the time. He tells us that he used to nag his son a lot: 'It was a lot of don't do this, and don't do that'. He explains to us that at the time he was in a difficult work situation, and he always felt uneasy: 'never at rest and never peaceful.' He now understood that he stressed his son with his own stress - 'my stress spilled over onto him.' At the time of the interviews he had a new job which he enjoys and he reported that he is feeling much better, and that his relationship with his son has improved accordingly.

Still, a distinct pattern emerges in these interview narratives that links ADHD with a lack of 'natural authority' associated with women and a feminized school. Jack says that he has accepted that his son is on medication at school, but at home he wants his son to be off drugs: 'The fights we have at home because he is off medication, I can handle them!' This utterance is made with pride in his voice and our interpretation is that having the power to raise their sons themselves is something these fathers are proud of. Jack regards medicalization as something mothers and the (female) teachers are in need of due to their lack of authority. This is evidence of a more general pattern in the interviews with the workingclass fathers, in which ADHD medication is considered as something that they distance and disassociate themselves from.

However, along with these patterns of distance and disassociation with femininity, these fathers express different forms of identification with their sons. They blame the dominant form of cultural upbringing, and consider hyperactivity in boys to be a result of too few possibilities for physical activity. Some of the other fathers maintain that they could remember themselves as having been even more active as children: 'I think I was somewhat 
worse than he is'. In the narratives of their own childhoods they recall how it was to be an active boy, which may explain why these fathers did not understand their son's level of activity as pathological. When asked if he thought he could have been diagnosed with ADHD as a boy, Frank refuted this:

Because when I was growing up, ADHD had not been invented and children were outside and played. They did not sit in front of a computer or TV all the time. When I came home in the evening I was tired, I had played all day with friends and I went straight to bed.

In order to understand their sons' behaviour and their own activity level as children, they draw on a 'boys will be boys' discourse characterized by a more traditional gender understanding, in which boys are naturally more active than girls. Importantly, this narrative also involves a strong form of empathy with their sons, particularly when it comes to the effect of being medicated. Like other working-class interviewees, Jonathan feels that his son's masculinity is threatened when he is on medication.

When Jonathan was asked what he thought were his son's feelings towards the medication regime, he said:

Like shit, I think. He didn't want to take them. I don't know why. I think it's something to do with his self-perception; he wants to try to fend for himself. Who would want to be on tablets all day?

Jonathan expresses sympathy with his son and thinks that having to take drugs every day can be a burden and have a negative influence on identity. Other fathers too observe that their sons have become less active while on drugs. This seems to raise a concern for their masculinity. Jonathan thought it was great when his son started on medication: 'Then he was not racing around all the time.' However, what he describes as a positive effect also worries him:

He is not aggressive at all. How will he be able to defend himself? He is supposed to be a boy, too. He is not supposed to be quiet 24 hours a day.

Jonathan seems concerned about his son being less of a boy because of the 'therapeutic' effect of reducing the son's behavioural activity. He is afraid the son fails to perform according to what this father considers to be appropriate masculinity - to be tough and aggressive enough to defend yourself in a fight. The pattern seems to be that when the medication effect turns 
active to passive, it conflicts with the father's ideals of masculinity and expectations of how a boy should be.

Along with this concern about passivity and weakness, the fathers also express a sincere concern for their sons' wellbeing. Jonathan dreams about the possibility that his son could one day stop taking the drug: 'So he can be the person he is supposed to be'. Typically, these fathers emphasize the times when their sons are doing well without the medication. Even though their sons do not always live up to the expectations of school and society, they are nevertheless perfectly fine in the eyes of their fathers: 'I think my son is a wonderful chap,' says Jonathan. Many of these fathers revealed a sense of pride in their sons, and some pointed out that the son was doing better at school than they did themselves. Though some noticed that the medication helped their sons to perform better in school, this did not seem to make them more invested in it. Instead, they pointed out that their son managed very well when he was involved in something of interest to him. Some recognized the changing demands in the labour market and appreciated the help their sons were given at school. But few of these fathers expressed concern for their sons' future during the interviews. They saw their sons as resourceful and were reasonably sure their sons would manage well if they only got a job.

\section{Reflexivity, shame and anxiety - middle-class fathers' narratives}

The middle-class fathers were also concerned about the medication. Instead of placing the blame for the diagnosis on the mother, the middle-class fathers, typically living in more gender-equal family structures, more often blamed the organization of the school for their sons' diagnosis and medication. They experienced pressure from the school to adopt a medical framework for handling their son. Alan mentioned a meeting at school when his son was ten years old. In this meeting, the parents were told that their son required special needs education, but according to the headmaster, the school needed a diagnosis to account for the son's problems at school and to provide the resources for organizing such education. Chris expressed very directly his lack of confidence in the school's organization of the teaching:

Why does he have to have some kind of medical disease to get the help he needs in school? [...]. It ought to be enough that he fails to pay attention in class. Instead he's been drugged so that he will manage to sit still.

According to Chris, it is not enough to place the blame on schools: 'Frankly it is about politics.' He talks about the medical framework for handling problem behaviour in boys as 
politically motivated. Chris also reflects about the parents' own contributions to the increase in medicalization of male behaviour in schools.

Ambitious middle-class parents who want to see their child as clever and unique put a lot of pressure on the teachers [...]. You have those parents of girls, who attend parents' meetings and proclaim that 'someone has to stop those hooligans.' This puts a lot of strain on the teachers who become anxious and stressed and as a result, the teachers' tolerance for interruptions and disruption is reduced.

For Chris, his son's ADHD diagnosis and drug treatment do not exist 'in a vacuum' but rather are part of a broader dynamic between politicians, schools and ambitious middle-class parents who want to raise successful children. When the middle-class fathers referred to their sons' teaching situation at school, they emphasized gender in similar ways to the working-class fathers. Some used the discourse of the feminization of state schools as an explanation for their sons' problems in school, claiming that the feminized pedagogy practised by women teachers placed the boys at a disadvantage. Two fathers said that their sons had been doing much better in school after they were given a new teacher. When asked to elaborate on what it was about this new teacher, their answer was: 'He is a man.'

The middle-class fathers also criticized the medical experts. Some claimed that the ADHD examination of their sons had been superficial and that the doctor was too quick to suggest stimulant drug treatment. Peter even questioned the validity of the diagnosis:

If you react to medicine by being quieter, it may be concluded that you have ADHD. [...] Ultimately, there are few good facts you have about ADHD. [...] So, I feel that the diagnosis is, very largely, you might say, medicine-based.

Behind these reflections on the ADHD diagnosis, it is possible to detect a deep scepticism of the medical experts and the legitimization of the diagnosis.

Like the working-class fathers, the fathers in this group sympathized with their sons and felt sorry for them. They identified with the feeling of being different from other boys and of being diagnosed and subjected to stimulant drug treatment. Peter was sure that, when he saw his son sitting quiet and thoughtful, he was sadly pondering on why he had to be diagnosed and drugged. Perhaps this was a projection of his own feelings from boyhood, as this father mentioned in the interview that he himself had struggled with low self-esteem and felt lonely and isolated when he was a boy. The fathers used different kinds of identification narratives about their sons' 'ADHD behaviour'. Some of the fathers even suggested possible 
genetic ties. Andrew said he actually thought that he had had ADHD as a child himself. This was the reason why he had wanted an ADHD assessment of his son.

Yet, in spite of these widespread identifications with their sons and scepticism towards medication, the middle-class fathers' narratives were generally more ambiguous. Various expressions of shame, guilt and anxiety were more common among the middle-class fathers. In contrast to the working-class fathers, the middle-class fathers more often emphasized their sons' weaknesses and the shame of having a son who fails to live up to society's expectations. They were ashamed when their sons did not follow the rules and when they exhibited behaviour that was out of control. Alan said he remembered himself as a responsible kid, always on time and in control, in contrast to how he observed his own son to be:

He reacts so violently to things, things that there is no reason to react to so violently. If things are not going the way he has anticipated, he reacts with screaming and howling and defiance. It worries me that he does not have the ability to think...

The shame and irritation Alan feels when his son exhibits a lack of self-control is also combined with a continuing worry about the son's future. How will he be able to succeed with that kind of behaviour? Although these worries about the future encourage the medication regime, these fathers seemed to remain ambivalent; they continue to wonder whether their sons actually need medication and some feel guilty about the drug treatment. Alan had the feeling that he was drugging his son and that he was taking something away from him. He remembered his son as a very happy boy:

He was a very happy boy although he did pull pranks and was like that, and of course he could have periods where he was very difficult, but now I feel he is not really happy. He was a much happier boy before.

The excerpt shows, as we see it, the father's guilt and concern for the changes he can see in his son's personality as a result of medication - how he perceives his son as deprived of his high spirits and freedom of self-expression. Just as Jonathan mentioned earlier, Alan wished his son could stop taking the drug, and manage without medication. Yet, in Alan's narrative, as among middle class fathers' narratives more generally, a combination of shame and guilt is more prominent.

However, when the medication effect encourages accomplishments on the football field, middle-class fathers are relieved. The fathers' desire to have sons who perform well in sport is another aspect of identification and was felt to be a relief from the embarrassment of 
watching a son who is not concentrating on the ball. The fathers had been boys themselves and know that if a youngster is to have a chance of being ranked among the popular boys at school, he should be good at sport. Athletic performance is incorporated in what is perceived as popular masculinity, and achievements on the football field are a particular route to masculine success among young people.

Several of the fathers perceived their sons as more coordinated and concentrated on the football field when on medication. Those who had a son who used Ritalin and not a depot methylphenidate tended to postpone the last pill to the days when their sons had football training so that the effect would be optimal. When talking to the fathers about their everyday life with their sons it appears that they use medication strategically to enhance their sons' performance. Some of the fathers viewed their sons as becoming faster and more persistent in winter sports. After starting on Ritalin, they could go cross-country skiing with their fathers on weekends. However, according to William, his son's rapid pace was probably because he was 'high on drugs'. While appreciating the positive effects of medication, this father also worried about possible side-effects. Generally, the fathers' resistance to the medication and their desire to have their sons perform well when participating in sports were clearly in conflict. When they decided for or against continuing the medication, they weighed the benefits against its negative effects, as found by Hansen and Hansen (2008). Peter used the following words: 'On the whole, the medication gives a net profit.'

What differentiated the middle-class fathers' conflictual narratives about the drug from those of the working-class fathers was their emotional investment in the drug's positive effects on their sons' behaviour. They feared that their sons' shortcomings would result in low self-esteem and failure in school, with consequences for their future educational trajectory. When their sons followed the medication regime, the fathers were less anxious about the future. In this context, they seemed to view the medication as a necessary evil. Nicolas said he knew they were lucky because his son did tolerate the stimulant treatment without troublesome side effects. Nicolas felt that the drug released his son from his undesirable and aggressive behaviour and made it possible for his real self to emerge: 'The medication allows the best version to emerge, strange to observe really, but it is how we know him'. This kind of authenticity narrative where the drug is perceived as a type of catalyst which can release their sons' full potential, contrasts with the working-class fathers who said that they experienced their real son to be the person off medication. 
Perhaps also because these middle-class fathers typically practised a form of socialization that is based more on negotiation, they experienced a feeling of being helpless and devoid of tools when they could not reason with their sons. To a certain extent, therefore, the drug treatment created a feeling that fatherhood and masculinity were restored.

\section{Father and son - gender and class}

In different ways all the fathers in the current study seemed to defend their sons against the diagnosis and medication, whether the fathers experienced their sons' diagnosis as being a result of something the mother wanted, or believed that the school or government health policies played an important part in their perceptions and narratives. This finding echoes those of other studies which indicate that fathers generally appear to be less susceptible to societal expectations of parents than do mothers (Dermott, 2009; Shirani et al. 2011). This is largely explained in terms of fathers' lack of involvement and mothers' persistent moral and emotional responsibility (Dermott, 2008; Doucet, 2007). There is little doubt that the gendered arrangement in the families in our study has an impact on the different ways of relating to ADHD. Certainly, the working-class fathers seemed to be more distanced from everyday responsibilities and could therefore more easily express their dislike of medication without having to face the problematic aspects of their sons' behaviour. Medication is a 'women's issue'. By contrast, most middle-class fathers used the word 'we' when they talked about the decision to start their son's drug treatment. In the families that practised equal childcare, the father and mother felt more equally responsible for the ADHD assessment and drug treatment. When the son's behaviour is not viewed as only the mother's responsibility, but the father's too, he also feels the emotional burden of having a child who does not behave according to the normative rules, and this may explain why the middle-class fathers, although also sceptical of the ADHD diagnosis, seemed to appreciate the medication effect more.

Fathers' more articulated resistance to dominant discourses is also explained in terms of their ability to draw on practices of hegemonic masculinity. This enables them to act with more autonomy, independence and self-reliance than mothers (Doucet, 2007; Shirani et al. 2011). This explanation seems less appropriate to explain the described pattern in our study. Certainly, the middle-class fathers articulate stronger criticism of the schools concerned. Yet, in spite of the noticeable ambiguities they tended to be less critical and more positive towards the effect of the drug. These fathers, who presumably should possess more resources in terms of self-reliance and autonomy, are also more invested in school achievement and athletic 
performance, and the medication effect is therefore perhaps easier to appreciate. By contrast, the working-class fathers, who presumably should feel less self-reliant, articulate a stronger resistance. Thus, rather than it being a matter of more or less emotional involvement, we suggest that the more fathers are invested in equal childcare shared with their wives, the more parental responsibilization becomes ingrained in these fathers; they feel responsible for their sons' emotional and cognitive development and for this reason they are more willing to accept the medical framework for handling their sons' problem behaviour. This is obviously enforced by classed differences in parenting style. While the working-class fathers seemed to be oriented towards their sons' present situation and their well-being here and now, the middle-class fathers were typically more concerned with the future. These middle-class fathers expressed anxiety about their child's future and worried more about his educational trajectory (see Reay, 2000; Stefansen and Aarseth, 2011; Vincent and Ball, 2007). Medication seemed to constitute an investment that alleviated this anxiety.

On the other hand, we suggest that there is something more to the working-class fathers' resistance to medicalization described here, than a lack of emotional responsibility or less vulnerability to future-oriented anxieties. We suggest that the resistance apparent in the narratives of the working-class fathers could be conceived of in terms of the distinction between emotional involvement that is less part of an achievement, something to be worked at, and emotional involvement that is considered as part of a more emergent bond or a 'natural trajectory' (Plantin, 2007). These working-class interviewees conceive of their involvement as fathers as something that happens in continuity with their own life trajectories and accordingly, in their emotional involvement with their child they draw on their own deepseated gendered identity. They put more emphasis on hard practical work and physical strength and were less inclined to highlight the positive effects of the drug treatment. When it had the effect of reducing their sons' energy level, the drug even seemed to create a fear of demasculinization. In order to make sense of this, we take inspiration from Eerola and Mikkännen (2013) who found that working-class men in their study formed a 'counternarrative' to the 'meta-narrative' of the emotionally involved 'new father'. While emotionally involved and sincerely child-centred, some of their interviewees were also protagonists of a dominant masculinity characterized by an emphasis on toughness and the ability to fend for yourself physically $(2013$, p. 17). We suggest that the working-class fathers in our study in a similar way use their masculine identity in a 'counter-narrative' to the dominant requirements 
for future-oriented parenting and more particularly to the medicalization discourse that could be seen as associated with these.

\section{Conclusion}

In this article, the experience of ADHD diagnosis and medication and the pressure on parents in Norwegian society to adhere to this dominant regime is used as a case to explore classed and gendered patterns in fathering. Although all the fathers seem to experience more resistance to medication compared to the mothers, we have emphasized some differences in the form this takes. The middle-class fathers' narratives are imbued with ambiguities. Despite resistance, they are more invested in medication and this investment seems to arise from and also to alleviate anxieties about the future. The working-class fathers seem to accept medication, but do not invest emotionally in it. On the contrary, they maintain a safe distance from the notion of medication, by seeing it as something related to femininity and partly also as a lack of masculinity. For them, medication is also something that is related to school and society at large. When it comes to their own relationship with their son, medication appears as something threatening. It is threatening to masculine virtues such as the ability to fend for oneself as well as to the fathers' experience of how their son really is and his well-being here and now. While the interviews with the working-class fathers relate to a classed masculinity linked to virtues such as strength and the ability to fend for yourself, that enables them to see their sons from another point of reference, the middle-class fathers harbour much more ambiguous feelings, as they partly identify with the discourse of achievement and academic success.

These differences do not easily fit into the picture of working-class fathers as less emotionally involved. Instead, the way fathers perceive their sons' diagnosis provides us with a window that enables us to conceive of differing patterns of emotional involvement. Whereas middle-class fathers are more invested in future possibilities, the working-class interviewees are more invested in and bonded to their sons by a shared belonging and shared (gender) identity. Their own experiences of being a boy are foremost in relation to their own sons. This may cause them to identify with their sons in a way that perhaps makes them more sensitive to the potential burden of being diagnosed with ADHD and treated with stimulant drugs on a daily basis. We argue that these classed masculinities in different ways enable the fathers to assume a love-driven identification with their sons' problematic 'masculine' behaviour. Seen in a wider context, the fathers' critical voices, which are most pronounced from the standpoint 
of working-class masculinity, offer considerable resistance to the medicalization discourse and thus also to currently dominant parenting regimes.

\section{References}

Aarseth, H, 2009, From Modernized Masculinity to Degendered Lifestyle Projects, Men and Masculinities, 11, 424-440

Andenæs, A, 2005, Neutral claims - gendered meanings: parenthood and developmental psychology in a modern welfare state, Feminism \& Psychology, 15, 209-226

Bekkengen, L, 2006, Men's parental leave: A manifestation of gender equality or childorientation, in L. Gonäs and J. Karlsson (eds), Gender Segregation: Divisions of Work in Post-industrial Welfare States, UK: Ashgate

Bourdieu, P, 1998, Practical Reason, Cambridge: Polity Press

Bowden, G, 2014, The merit of sociological accounts of disorder: The attention-deficit hyperactivity disorder case, Health, 18, 422-438

Brandt, B, 2012, Emotional dimensions of fathering and work - life boundaries, in P. McDonald and E. Jeanes (eds), Men, Wage Work and Family London: Sage, 114-128

Bernstein, B, 1977, Class, Codes and Control, London: Routledge

Brannen, J, Nilsen, A, 2006, From fatherhood to fathering: Transmission and change among British fathers in four-generation families, Sociology 40, 335-352

Braun, A, Vincent, C, Ball, S. J., 2011, "Working-class fathers and childcare: the economic and family contexts of fathering in the UK ", Community, Work \& Family 14, 19-37

Center for disease control and prevention (CDC). Data \& Statistics. Updated 31.03.2015, http://www.cdc.gov/ncbddd/adhd/data.html

AA, Mothers and fathers attributions and beliefs in families of girls and boys with attentiondeficit/hyperactivity disorder, Child Psychiatry and Human Development, 39, 85-99

Coltart, C, Henwood, K, 2012, On parental subjectivity: a qualitative longitudinal and psychosocial case analysis of men's classed positions and transitions to first-time fatherhood, Qualitative Research, 12, 35-52

Conrad, P, 2010, A symposium on attention deficit hyperactivity disorder, The changing social reality of ADHD. Contemporary sociology. A journal of reviews, 39, 525-529

Conrad, P, 2006, Identifying Hyperactive Children: The Medicalization of Deviant Behaviour, London: Ashgate

Dermott, E, 2008, Intimate Fatherhood: A Sociological Analysis, London: Routledge 
Doepke, M, Zilibotti, F, 2014, Parenting with Style: Altruism and Paternalism in Intergenerational Preference Transmission, Cambridge: National Bureau of Economic Research

Dolan, A, 2014, 'I've Learnt What a Dad Should Do': The Interaction of Masculine and Fathering Identities among Men Who Attended a 'Dads Only' Parenting Programme Sociology, 48, 4812-828

Doucet, A, 2007, Do Men Mother? Toronto: University of Toronto Press

Eerola, P, Mikkännen, J, 2013, Paternal Masculinities in Early Fatherhood. Dominant and Counter Narratives by Finnish First-Time Fathers, Journal of Family Issues, 36, 16741701

Farstad, G.H, Stefansen, K, 2015, Involved fatherhood in the Nordic context: dominant narratives, divergent approaches, NORMA, 10, 55-70

Finn, M, and Henwood, K, 2009, Exploring masculinities within men's identificatory imaginings of first-time fatherhood, British Journal of Social Psychology, 48, 547-562

Frances, A, 2012, DSM-5 further inflates attention deficit hyperactivity disorder, The Journal of Nervous and Mental Disease, 200, 486-488

Frigerio, A, Montali, L, Fine, M, 2013, Attention deficit/hyperactivity disorder blame game:

A study of the positioning of professionals, teachers and parents. Health, 17, 584-604

Frosh, S, Phoenix, and Pattman, R, 2002, Young Masculinities, Understanding Boys in Contemporary Society, Hampshire: Palgrave

Furman, L, 2009, ADHD: What do we really know?, in S, Timimi and J, Leo (eds) Rethinking ADHD: From Brain to Cultur,. Basingstoke, UK: Palgrave Macmillan, 21-57

Gillies, V, 2005, Raising the 'meritocracy': Parenting and the individualization of social class, Sociology, 39, 835-853

Gottzén, L, Kremer-Sadlik, T, 2012, Fatherhood and youth sports: a balancing act between care and expectations, Gender and Society, 26, 639-664

Haavind, H, 1987, Liten og stor: Mфdres omsorg og barns utviklingsmuligheter, Oslo: Universitetsforlaget

Hansen, D.L, Hansen, E.H, 2006, Caught in a balancing act: Parents' dilemmas regarding their ADHD child's treatment with stimulant medication, Qualitative Health Research, 16, 1267-1285

Hollway, W, Jefferson, T, 2005, Doing Qualitative Research Differently. Free Association, Narrative and Interview Method, London, UK: Sage

Idås, E, 2011, Et mangehodet vesen, Morgenbladet 30. September

Johansson, T, Klinth, R, 2008, Caring fathers. The ideology of gender equality and masculine positions, Men and Masculinities, 1, 42-62 
Lareau, A, 2003, Unequal Childhoods: Class, Race and Family life, Berkeley: University of California Press

Lunde, C, 2011, Fra hyperaktiv til sentralstimulant. Et essay om barnedoping, Samtiden, 3, 417

Olsvold, A, 2012, Når "ADHD" kommer inn dфren. En psykososial undersфkelse av barns, mødres og fedres forståelse og opplevelse av ADHD-diagnose og -medisinering. $\mathrm{PhD}$ Thesis, Department of Psychology. Faculty of Social Sciences. University of Oslo

Plantin, L, 2007, Different classes, different fathers? Community, Work and Family, 10, 93110

Reay, D, 2000, A useful extension of Bourdieu's conceptual framework? Emotional capital as a way of understanding mothers' involvement in their children's education, Sociological Review, 48, 568-585

Reay, D, Crozier, G, and James, D, 2011, White Middle-class Identities and Urban Schooling, Houndmills: Palgrave Macmillan

Ruddick, S, 1989, Maternal thinking. Towards a politics of peace, London: The Women's Press

Shirani, F, Henwood, K, Coltart, C, 2011, Meeting the challenges of intensive parenting culture: Gender, risk management and the moral parent, Sociology 46, 25-40

Singh, I, 2003, Boys will be boys: Father's perspectives on ADHD symptoms, diagnosis, and drug treatmen, Harvard Review of Psychiatry, 11, 308-31

Smette, I, 2015, The final year. An anthropological study of community in two secondary schools in Oslo, Norway, Department of Social Anthropology, Oslo: University of Oslo

Stefansen, K, Aarseth, H, 2011, Enriching intimacy: the role of the emotional in the 'resourcing' of middle-class children, British Journal of Sociology of Education, 32, 389-405

Stefansen, K, Farstad, G.R, 2010, Classed parental practices in a modern welfare state: Caring for the under threes in Norway, Critical Social Policy, 30, 120-141

Sullivan, O, 2010, Changing Differences by Educational Attainment in Fathers' Domestic Labour and Child Care, Sociology 44, 716-733

Timimi, S, 2009, Why diagnosis of ADHD has increased so rapidly in the West: A cultural perspective, in S, Timimi and J, Leo (eds) Rethinking ADHD: From Brain to Culture. Basingstoke, UK: Palgrave Macmillan, 133-159

Vincent, C, Ball, S.J, 2007, 'Making up' the middle-class child: Families, activities and class dispositions, Sociology, 41,1061-1077 
Vincent, C Maxwell, C, 2016, Parenting priorities and pressures: Furthering understanding of 'concerted cultivation', Discourse: Studies in the Cultural Politics of Education, 37, 269-281

Walkerdine, V, Lucey, H, and Melody, J, 2001, Growing Up Girl. Psychosocial Explorations of Gender and Class, Houndmills, Basingstroke, Hampshire, UK: Palgrave

Zoëga, H, Furu, K, Halldórsson, M, Thomsen, P.H, Sourander, A, Martikainen, J.E, 2011, Use of ADHD drugs in the Nordic countries: a population-based comparison study, Acta Psychiatrica Scandinavica, 123, 360-367

\footnotetext{
${ }^{\text {i }}$ Permission to conduct the interviews and to collect and store sensitive data was obtained from the Regional Committee for Medical and Health Research Ethics (REK) South East, Norway. The analyses were carried out from anonymized transcripts.
} 